\title{
Prevalence of C282Y and H63D mutations in the HFE gene of Brazilian individuals with clinical suspicion of hereditary hemochromatosis Prevalência das mutações C282Y e H63D no gene HFE em indivíduos brasileiros com suspeita clínica de hemocromatose hereditária
}

Alessandro C. S. Ferreira

Vanessa C. Oliveira

Fabiola A. Caxito

Karina B. Gomes

Amanda M. Castro

Victor C. Pardini

\begin{abstract}
Classical hereditary hemochromatosis is a recessive autosomal disease related to a systemic iron overload that is frequently related to C282Y and H63D mutations in the HFE gene. In Brazil, reports on HFE gene mutation frequencies are rare, mainly in regards to a representative sample population. This study intended to determine the prevalence of $C 282 \mathrm{Y}$ and $\mathrm{H} 63 \mathrm{D}$ mutations among individuals with clinical suspicion of hereditary hemochromatosis. A total of 1955 patients were studied with C282Y and H63D mutations being detected by the polymerase chain reaction technique followed by enzymatic restriction. The sample consisted of $76.6 \%$ men and $23.4 \%$ women. The highest percentage of analyzed individuals (56.9\%) was concentrated in the 41 to 60 year-old age group. Although there were no genic or genotypic differences between genders, a higher number of over 60-year-old women was observed. The C282Y mutation was found as homozygous in $2.9 \%$ of the cases and as heterozygous in $10.1 \%$, while the H63D was homozygous in $4.3 \%$ and heterozygous in $30.6 \%$. The C282Y and H63D mutant allele frequencies were 0.079 and 0.196 , respectively. The highest frequency was observed for H63D which was in genetic equilibrium. This work is important to determine the genetic profile of the population with hereditary hemochromatosis in Brazi. Rev. Bras. Hematol. Hemoter. 2008;30(5):379-383.
\end{abstract}

Key words: Hemochromatosis; genetic anomaly; HFE mutation.

\section{Introduction}

Classical hereditary hemochromatosis $(\mathrm{HH})$ is a recessive autosomal disease with a prevalence of between 1:200 and 1:500 individuals and is characterized by a systemic iron overload due to an inappropriate absorption by the intestine. ${ }^{1-4}$ The progressive iron accumulation generally causes structural damage and functional harm to several organs followed by inflammatory and oxidative events. Clinical manifestations predominate in men (two to three times more common in men than in women) while the absence of this phenotype is common in women due to monthly blood loss which decreases iron deposits in the body. ${ }^{2,5,6} \mathrm{HH}$ presents a long term latency ${ }^{7}$ and is divided into 3 stages: from 0 to 20 years old, in which there is no iron accumulation; from 20 to 40 , in which there is an iron overload, however, with no physiological damage, and over 40 , when there is an iron overload and damage to organs, initially with fibrosis and/or hepatic cirrhosis. ${ }^{8}$ Generally, clinical manifestations appear between the ages of 40 and 60 . The fifth decade is, in particular, the most common period among women for the onset of signs and symptoms. ${ }^{5,6}$ Classical hereditary hemochromatosis (Type 1) is associated to the presence of genetic variations in the HFE gene located in the short arm of the 6p21.3 chromosome..$^{1,9,10}$ An average of 20 mutations have been identified in this gene; ${ }^{5}$ nevertheless, there are two missense mutations, C282Y and H63D, which are more commonly associated to HH. ${ }^{1,8,11}$

Departamento de Genética Humana - Instituto Hermes Pardini - Belo Horizonte-MG

Correspondência: Alessandro Clayton de Souza Ferreira

Departamento de Genética Humana - Instituto Hermes Pardini

Rua Maranhão, 1040 - Funcionários

30150-330 - Belo Horizonte-MG - Brasil

Fax.: 5531 3228-6524

E-mail: alessandro@labhpardini.com.br 
The $\mathrm{C} 282 \mathrm{Y}$ mutation, in exon 4 , consists in a transition from guanine $(\mathrm{G})$ to adenine $(\mathrm{A})$ in nucleotide 845 , which determines the replacement of a cysteine (C) by a tyrosine (Y) in amino acid 282, incapacitating the interaction among HFE, transferrin and $\beta 2$-microglobulin. ${ }^{1,4}$ These data support clinical findings which report that $\mathrm{C} 282 \mathrm{Y}$ mutant homozygotes have a two-fold higher probability of presenting with hepatic diseases. ${ }^{7,12,13}$ Most studies identify C282Y as the main mutation responsible for $\mathrm{HH}$, with $\mathrm{HH}$ frequencies being influenced by ethnical variables., ${ }^{2,4,6}$ A transversion from cytidine $(\mathrm{C})$ to guanine $(\mathrm{G})$ in nucleotide 187 reflects in the replacement of histidine $(\mathrm{H})$ by aspartic acid (D) in amino acid 63, thereby determining the H63D mutation, which consequently results in a change in HFE protein conformation minimizing its binding affinity to transferrin. ${ }^{3,10}$ Generally, this is associated to mild forms of $\mathrm{HH} .{ }^{1,4,11}$ A minority of C282Y/ H63D heterozygotes ( 1 to $2 \%$ on average) develop clinical symptoms of hemochromatosis; ${ }^{2,9}$ Beutler et al. ${ }^{14}$ reported that, generally, Caucasians with clinical evidence of $\mathrm{HH}$ are either homozygous for $\mathrm{C} 282 \mathrm{Y}$ or compound heterozygous for C282Y/H63D.

It is a scientific consensus that HFE gene mutations are more frequent in the Caucasian population, however, there are discrepancies among the diverse world populations. In Brazil, reports on the frequencies of these mutations and their relationship to clinical manifestations are rare, in particular when analyzing a representative sample population. The purpose of the present study was to determine the prevalence of $\mathrm{C} 282 \mathrm{Y}$ and H63D mutations in the HFE gene among Brazilian individuals with clinical suspicion of hereditary hemochromatosis, according to the age and gender.

\section{Material and Method}

\section{Clinical material}

The study is the retrospective statistical analyses of data registered on 1955 individuals who were submitted to molecular studies of the $\mathrm{C} 282 \mathrm{Y}$ and H63D mutations at the Instituto Hermes Pardini, Human Genetics Department, Belo Horizonte, Minas Gerais state in 2006. All patients had a clinical suspicion of hereditary hemochromatosis. The age average was $48.8 \pm 13.8$ years old. The sample consisted of 1498 men and 457 women. Gender, age and genotype for C282Y and H63D were analyzed for these individuals.

\section{C282Y and H63D mutation genotyping}

Genomic DNA was extracted from leukocytes of

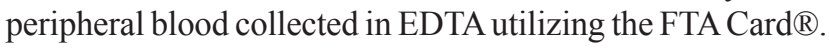
C282Y and H63D mutations were detected by the Polymerase Chain Reaction technique followed by enzymatic restriction (PCR-RFLP); utilizing specific oligonucleotides C282YR: 5' CTCAGGCACTCCTCTCAACC 3', C282YF: 5' TGG CAA GGGTAAACAGATCC 3', H63DR: 5' GCCACATC TGGCT TGAAATT 3' and H63DF: 5' ACATGGTTAAGGCC TGTTGC
3'.1 The PCR products for C282Y and H63D were digested, respectively, by the restriction endonucleases RsaI and $\mathrm{BclI}$, specific for each site of mutations. ${ }^{15}$ The denominations $282 \mathrm{CC}$ (63HH), 282CY (63HD) and 282YY (63DD) refer to the wild allele, and heterozygous and homozygous mutations of C282Y, respectively. Fragments of 247 and $140 \mathrm{pb}$ are encountered for the wild allele (282CC) and of 247, 111 and $29 \mathrm{pb}$ for the homozygous allele (282YY). In the presence of the homozygous allele (63DD), only one fragment of $208 \mathrm{pb}$ is observed, while fragments of 138 and $70 \mathrm{pb}$ correspond to the wild allele $(63 \mathrm{HH})$. The products were viewed in $7 \%$ acrylamide gel and evinced by SyBR ${ }^{\circledR}$ Safe DNA gel stain (Invitrogen $\mathbb{R}$ ).

\section{Statistical analysis}

The clinical and molecular characteristics of the studied individuals were analyzed utilizing the chi-square test (BioStat 4.0 Software). The Hardy-Weinberg Equilibrium was analyzed with the Genepop Software (on-line version.) ${ }^{16}$ Values for $\mathrm{p}<0.05$ were considered significant.

\section{Results}

\section{Prevalence of mutations}

This study evaluated the data registered for 1955 individuals with clinical suspicion of hereditary hemochromatosis, who were submitted to genotyping examinations for $\mathrm{C} 282 \mathrm{Y}$ and $\mathrm{H} 63 \mathrm{D}$ mutations. The $\mathrm{C} 282 \mathrm{Y}$ mutation was presented as homozygous in $2.9 \%$ of the individuals and heterozygous in $10.1 \%$, while the H63D mutation was homozygous in $4.3 \%$ and heterozygous in $30.6 \%$. The allele frequency was 0.196 for H63D and 0.079 for C282Y. Compound heterozygosity (C282Y/H63D) was observed in $3 \%$ of the cases. It is interesting to note that the 56 (2.8\%) homozygous individuals for the C282Y (282YY) mutation presented with the wild genotype for H63D in the same way that the 84 (4.3\%) homozygous for the H63D (63DD) mutation had the wild genotype for $\mathrm{C} 282 \mathrm{Y}$.

\section{Gender}

This sample consisted of $76.6 \%$ (1.498) men and $23.4 \%$ (457) women, resulting in a 3:1 proportion. The allele frequency of the C282Y mutation was 0.095 in women and 0.074 in men. The allele frequency of the H63D mutation was 0.206 in women and 0.194 in men. There was no significant genic differences between the genders on analyzing the presence of the mutations $(\mathrm{p}=0.1)$. The studied population, independently of the gender, did not present genotypic differences when the two loci, C282Y and H63D, were analyzed together $(\mathrm{p}=$ 0.18 ) or separately $(\mathrm{C} 282 \mathrm{Y}, \mathrm{p}=0.09 ; \mathrm{H} 63 \mathrm{D}, \mathrm{p}=0.46)$.

Age

The individuals were divided into four age groups ( 0 to 20,21 to 40,41 to 60 and $\geq 61$ years). The highest percentage 


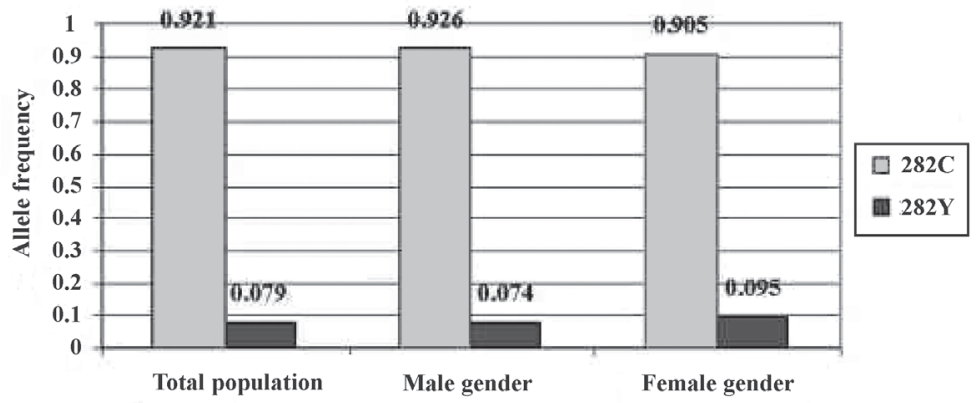

Figure 1. Allele frequencies of mutation $\mathrm{C} 282 \mathrm{Y}$ according to the population type

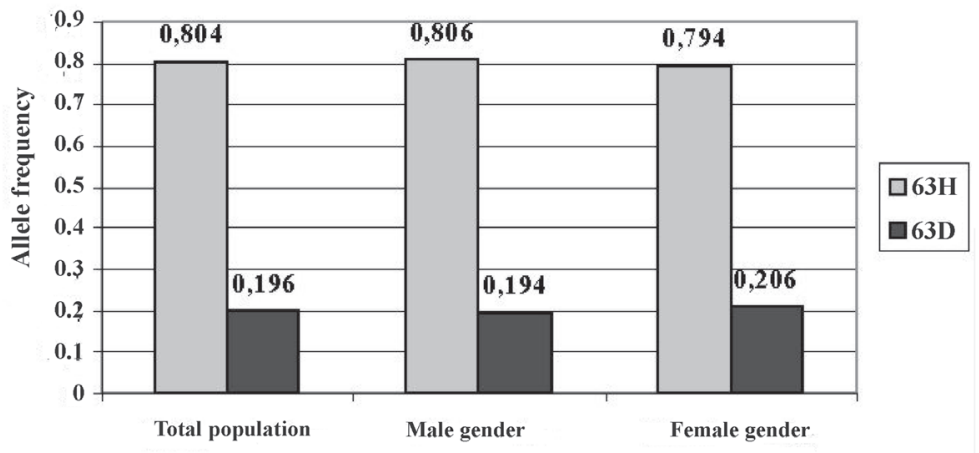

Figure 2. Allele frequencies of mutation $\mathrm{H} 63 \mathrm{D}$ according to the population type

of individuals analyzed for $\mathrm{C} 282 \mathrm{Y}$ and $\mathrm{H} 63 \mathrm{D}(56.9 \%)$, with suspicion of $\mathrm{HH}$ were concentrated in the 41 to 60 age group, with $44.6 \%$ being female and $60.6 \%$ male. Almost $31.5 \%$ of women presented with ages equal to or greater than 61 years old, against $14.4 \%$ of men, and $5.5 \%$ of female individuals against $2.5 \%$ of male were in the 0 to 20 age group. In the 21 40 age group $44.6 \%$ were women and $60.6 \%$ men. The 0 to 20 age group was significantly smaller when compared to the 21 to 40 age group ( $\mathrm{p}=0.0006$ ). It is also significantly smaller than the 41 to 60 age group $(\mathrm{p}<0.0001)$. The size of the 21 to 40 and 41 to 60 age groups did not present any significant difference; but the number of over 61-year-old women (31.5\%) was statistically greater $(\mathrm{p}<0.001)$ than over 61 -year-old men
(14.4\%). Individuals classified by age group and gender did not represent significant differences between the $\mathrm{C} 282 \mathrm{Y}$ and $\mathrm{H} 63 \mathrm{D}$ genotype frequencies $(\mathrm{p}>0.05)$. (Table 1)

\section{Hardy-Weinberg equilibrium}

On analyzing this study sample, the genotypic frequencies of $\mathrm{C} 282 \mathrm{Y}$ and $\mathrm{H} 63 \mathrm{D}$ mutations together do not follow the Hardy-Weinberg equilibrium ( $p=$ high significance). However, when the loci were analyzed separately, the $\mathrm{C} 282 \mathrm{Y}$ mutation is not in the Hardy-Weinberg equilibrium $(\mathrm{p}=$ high significance $)$ while the H63D mutation is in equilibrium $(\mathrm{p}=0.46)$.

\section{Discussion}

The frequencies of $\mathrm{C} 282 \mathrm{Y}$ and $\mathrm{H} 63 \mathrm{D}$ mutations found in this study are greater than those reported for the general Brazilian population, , $1,8,11,13,15,17-22$ but are smaller than the genotypic frequencies among patients with HH. ${ }^{2,3,4}$ It is unquestionable that $\mathrm{C} 282 \mathrm{Y}$ is the main mutation responsible for $\mathrm{HH}$ in all studied populations, as the majority of published reports worldwide cite its prevalence in more than $80 \%$ of individuals with clinical manifestations of $\mathrm{HH}, 1,4-6,12,15,17,23$ thus several other diagnostic guides are based on the result of $\mathrm{C} 282 \mathrm{Y}$ mutation genic testing., ${ }^{2,67,15}$ It is not different for the Brazilian population, as in the paper by Bittencourt et al., ${ }^{1}$ homozygous individuals for this mutation present an earlier onset for pathological aspects compared to heterozygous individuals with an onset at an earlier age than the wild allele, $282 \mathrm{CC}$. The allele frequency of $282 \mathrm{Y}$ in the present study was $7.9 \%$; a rate considerably greater than other Brazilian studies $(2 \%$ in general population), ${ }^{11}$ indicating a relationship between this mutation and clinical suspicion of $\mathrm{HH}$.

The proportion of 3:1 between the men and women genotyped for the two mutations, is in accordance with several published studies that, in unanimity, justify this fact

Table 1. Genotypic frequencies for $\mathrm{C} 282 \mathrm{Y}$ and $\mathrm{H} 63 \mathrm{D}$ mutations, according to the gender and age of the studied population

\begin{tabular}{|c|c|c|c|c|c|c|c|c|c|c|c|c|c|c|c|c|c|c|c|c|c|}
\hline & \multicolumn{7}{|c|}{ All population } & \multicolumn{7}{|c|}{ Female population } & \multicolumn{7}{|c|}{ male population } \\
\hline & \multicolumn{2}{|l|}{ Total } & \multicolumn{2}{|l|}{$\mathrm{C} 282 \mathrm{Y}$} & \multicolumn{3}{|c|}{ H63D } & \multirow[t]{2}{*}{ Total } & \multicolumn{3}{|c|}{$\mathrm{C} 282 \mathrm{Y}$} & \multicolumn{3}{|c|}{$\mathrm{H} 63 \mathrm{D}$} & \multirow[t]{2}{*}{ Total } & \multicolumn{3}{|c|}{$\mathrm{C} 282 \mathrm{Y}$} & \multicolumn{3}{|c|}{ H63D } \\
\hline \multicolumn{20}{|c|}{ Genotyping Frequency } & & \\
\hline $\begin{array}{l}\text { Age } \\
\text { Group }\end{array}$ & $\%^{\text {a }}$ & $\mathrm{CC}$ & $\mathrm{CY}$ & YY & $\mathrm{HH}$ & $\mathrm{HD}$ & DD & $\% b$ & $\mathrm{CC}$ & $\mathrm{CY}$ & YY & $\mathrm{HH}$ & HD & $\mathrm{DD}$ & $\%^{c}$ & $\mathrm{CC}$ & $\mathrm{CY}$ & YY & $\mathrm{HH}$ & $\mathrm{HD}$ & $\mathrm{DD}$ \\
\hline 0 to 20 years & 3.2 & 0.839 & 0.113 & 0.048 & 0.516 & 0.419 & 0.065 & 5.5 & 0.800 & 0.120 & 0.080 & 0.520 & 0.440 & 0.04 & 2.5 & 0.865 & 0.108 & 0.027 & 0.514 & 0.41 & 0.08 \\
\hline 21 to 40 years & 21.5 & 0.850 & 0.124 & 0.026 & 0.637 & 0.316 & 0.048 & 18.4 & 0.821 & 0.143 & 0.04 & 0.643 & 0.321 & 0.036 & 22.5 & 0.858 & 0.208 & 0.021 & 0.635 & 0.32 & 0.05 \\
\hline 41 to 60 years & 56.9 & 0.836 & 0.088 & 0.026 & 0.668 & 0.299 & 0.032 & 44.6 & 0.868 & 0.098 & 0.03 & 0.652 & 0.324 & 0.025 & 60.6 & 0.89 & 0.086 & 0.024 & 0.671 & 0.29 & 0.03 \\
\hline$\geq 61$ years & 18.4 & 0.850 & 0.114 & 0.036 & 0.636 & 0.297 & 0.067 & 31.5 & 0.847 & 0.125 & 0.04 & 0.625 & 0.29 & 0.083 & 14.4 & 0.856 & 0.106 & 0.037 & 0.644 & 0.3 & 0.06 \\
\hline Total frequency ${ }^{d}$ & 100 & 0.87 & 0.101 & 0.029 & 0.651 & 0.306 & 0.043 & 100 & 0.847 & 0.116 & 0.04 & 0.635 & 0.32 & 0.046 & 100 & 0.877 & 0.117 & 0.025 & 0.656 & 0.3 & 0.04 \\
\hline Sampling $\mathrm{N}^{\mathrm{e}}$ & 1955 & 1701 & 198 & 56 & 1272 & 599 & 84 & 1498 & 387 & 53 & 17 & 290 & 146 & 21 & 457 & 1314 & 145 & 39 & 982 & 453 & 63 \\
\hline
\end{tabular}


by the "protective effect" of monthly bleeding and pregnancy by which the plasma concentration of iron is reduced because of the periodic physiological blood loss. ${ }^{3,5}$ As it was expected, when assessed together, there was no statistical difference in the genotypic frequencies of $\mathrm{C} 282 \mathrm{Y}$ and H63D between genders due to the fact that both are autosomally inherited.

Remembering that the studied population has clinical suspicion of $\mathrm{HH}$ and that in the majority of the cases the request for genic examinations is in order to confirm diagnosis, it is plausible that the concentration on individuals in the 41 to 60-year age group is evidence of the late development of HH. Generally, after 40 years old, the individual has lived long enough to allow iron accumulation to a pathological level. ${ }^{3,6,17}$ Younger patients usually present milder clinical manifestations when compared to the advanced age group. ${ }^{3}$ The fact that $31.5 \%$ of women present with ages equal to or greater than 61 years old against $14.4 \%$ of men is due to the intrinsic iron metabolism of the female organism and also because the menstrual cycle has finished. It is important to observe that there is scientific agreement regarding the onset of clinical manifestations of $\mathrm{HH}$ normally during or after the age of 50 among women ${ }^{5,6}$ and, also manifestations of $\mathrm{HH}$ becoming apparent later than for men and are often milder. ${ }^{16}$ Therefore, the presence of more female individuals than male in the 0 to 20 age group might be of a random nature, since, at this age the genetic testing of the HFE gene is generally to screen children with affected parents or might indicate the necessity of genetic tests for other genes, a situation that could not be confirmed in this study.

The fact that $\mathrm{C} 282 \mathrm{Y}$ mutation was not in HardyWeinberg equilibrium may indicate the existence of natural selection of homozygous individuals. ${ }^{18}$ Nevertheless, a study of 41,038 individuals considered Caucasians, from the USA, reported that the $\mathrm{C} 282 \mathrm{Y}$ mutation is in balance. ${ }^{14}$ Additionally, there is a deficit of heterozygous individuals for $\mathrm{C} 282 \mathrm{Y}$ $(p>0.05)$, a fact that could be intrinsic in this study as the studied population was under clinical suspicion of $\mathrm{HH}$ and the symptoms rarely manifest in $282 \mathrm{CY}$ heterozygous individuals who are thus, generally, not submitted to genetic testing. This fact may show the failure of the heterozygous $282 \mathrm{CY}$ genotype, in an isolated form, to cause a phenotypic expression of HH. On the other hand, H63D obeys the HardyWeinberg equilibrium and does not present with a heterozygous deficit, probably because this mutation is common in our population.

Homozygous and heterozygous genotypes for the H63D mutation may show minor penetration at the onset of $\mathrm{HH}$ clinical manifestations. Although having a minor penetration, $\mathrm{H} 63 \mathrm{D}$ is of great importance in the development of $\mathrm{HH}$, whether homozygous or simultaneous with C282Y. Hence, it is considered an essential part of genetic tests which investigate the cause of $\mathrm{HH}^{3}$ In the present study, the allele frequency of H63D was 0.196 and in accordance with the majority of the other world populations, in which the frequency ranges from 0.1 to 0.2 ; it is important to note that Spain and Portugal, countries that greatly influenced colonization of Brazil, present frequencies greater than 0.2 in their general populations. ${ }^{4,11}$

The frequency of 0.03 for $\mathrm{C} 282 \mathrm{Y} / \mathrm{H} 63 \mathrm{D}$ compound heterozygotes is in accordance with data already reported for the American population, ${ }^{14}$ but it does not concur with Brazilian data, ${ }^{1,11,15,21,22}$ probably because of the quantitative difference of the studied populations and because of the fact that this paper assessed individuals with clinical suspicion of $\mathrm{HH}$. Thus, this frequency values the role of the $\mathrm{C} 282 \mathrm{Y} /$ H63D genotype in the development of HH. A Pietrangelo ${ }^{3}$ reported that about 1 to $2 \%$ of $\mathrm{C} 282 \mathrm{Y} / \mathrm{H} 63 \mathrm{D}$ compound heterozygous individuals are predisposed to the expression of $\mathrm{HH}$, a fact that provides them a distinct position in iron overload disease diagnostic guidelines. Another study cites that $11 \%$ of compound heterozygotes clinically manifest $\mathrm{HH}{ }^{2}$

The greater significance of heterogeneity of the $\mathrm{C} 282 \mathrm{Y}$ mutation compared to the H63D mutation might be caused by the higher frequency of homozygous and heterozygous genotypes for the latter mutation in the population and its lesser importance in the onset of $\mathrm{HH}$ clinical manifestations. Population studies of HFE gene mutations indicate that the allele frequency of $\mathrm{C} 282 \mathrm{Y}$ is 3 to 8 times lower in the Brazilian population than in north Europe, while these two populations have similar frequencies for H63D. The frequencies of HFE gene mutations encountered in Brazilian publications endorse the variability of the results found, as well as the inherent variables of each experiment (sample size, geographic inclusion of the population). ${ }^{1,8,11,13,15,19-22}$

Brazil is constituted by one of the most heterogeneous world populations, which reflects in the genetic parameters of different hereditary diseases, providing a genic diversity in the population and, also, the necessity of well conducted studies which assist in clarifying the enigmas of these diseases. With this in mind, the present paper shows the frequencies of $\mathrm{C} 282 \mathrm{Y}$ and $\mathrm{H} 63 \mathrm{D}$ mutations, according to gender and age aiming at helping the selection of diagnostic examinations, in respect to the populational profile of studied individuals, which could act as an important clinical benefit for health in Brazil.

\section{Resumo}

A hemocromatose hereditária clássica (HH) é uma doença autossômica recessiva caracterizada por uma sobrecarga sistêmica de ferro, a qual está freqüentemente relacionada às mutações $C 282 \mathrm{Ye}$ H63D no gene HFE. No Brasil, registros das freqüências das mutações no gene HFE são raros, principalmente envolvendo uma amostra representativa da população. Este estudo teve como objetivo a determinação da prevalência das mutações C282Y e H63D em indivíduos com suspeita clínica de HH. Para isto, foram estudados 1955 pacientes para os quais as mutações C282Y e H63D foram pesquisadas pela técnica de Reação em Cadeia da Polimerase seguida de digestão enzimática. A amostra consistiu de 76,6\% ho- 
mens e 23,4\% de mulheres. A maioria dos individuos analisados $(56,9 \%)$ estava concentrada no grupo de 41 a 60 anos. Embora não tenham sido observadas diferenças gênicas e genotípicas entre os gêneros, foi observado um maior número de mulheres na faixa etária acima dos 60 anos A mutação C282Y estava presente em homozigose em 2,9\% dos individuos e em heterozigose em 10,1\%, enquanto H63D estava presente em homozigose em 4,3\% e em heterozigose em 30,6\% dos individuos estudados. As freqüencias dos alelos mutantes C282Y e H63D foram de 0,079 e 0,196, respectivamente. Além de mais freqüente entre a população estudada, a mutação H63D mostrou equilíbrio genético, ao contrário da mutação C282Y. Este trabalho tem como importância a determinação do perfil genético da população acometida pela HH no Brasil. Rev. Bras. Hematol. Hemoter. 2008;30(5):379-383.

Palavras-chave: Hemocromatose hereditária; anormalidade genética; mutação HFE.

\section{References}

1. Analysis of HLA-A antigens and C282Y and H63D mutations of the HFE gene in Brazilian patients with hemochromatosis. Braz J Med Biol Res. 2002;35(3):329-35.

2. Limdi JK, Crampton JR. Hereditary haemochromatosis. QJM. 2004;97(6):315-24.

3. Pietrangelo A. Hereditary hemochromatosis--a new look at an old disease. N Engl J Med. 2004;350(23):2383-97

4. Cimburová M, Putová I, Provazníková $\mathrm{H}$, et al. S65C and other mutations in the haemochromatosis gene in the Czech population. Folia Biol (Praha). 2005;51(6):172-6.

5. Scotet V, Le Gac G, Mérour MC, et al. Impact of HFE genetic testing on clinical presentation of hereditary hemochromatosis new epidemiological data. BMC Medical Genetics 2005;6:24

6. US. Preventive Services Task Force. Screening for hemochromatosis: recommendation statement. Ann Intern Med. 2006; 145(3):204-8.

7. Gertig DM, Hopper JL, Allen KJ. Population genetic screening for hereditary haemochromatosis. Med J Aust. 2003;179(10):517-8.

8. Martinelli AL, Filho R, Cruz S, et al. Hereditary hemochromatosis in a Brazilian university hospital in São Paulo State (1990-2000). Genet Mol Res. 2005;4(1):31-8.

9. Guerreiro RJ, Bras JM, Santana I, et al. Association of HFE common mutations with Parkinson's disease, Alzheimer's disease and mild cognitive impairment in a Portuguese cohort. BMC Neurology. 2006;6:24.

10. Hemochromatosis. Em: Online Mendelian Inheritance in Man, OMIM. (Accessed April 02, 2007, em http://www.ncbi.nlm.nih.gov/ $\mathrm{omim} /$.)

11. Oliveira TM, Souza FP, Jardim AC, et al. HFE gene mutations in Brazilian thalassemic patients. Braz J Med Biol Res. 2006;39 (12): $1575-80$

12. Beutler E, Felitti VJ, Koziol JA, Ho NJ, Gelbart T. Penetrance of 845G--> A (C282Y) HFE hereditary haemochromatosis mutation in the USA. Lancet. 2002;359(9302):211-8

13. Domingos CRB. Hereditary hemocrhomatosis and HFE gene mutations. Rev Bras Hematol e Hemoter. 2006;28(4):239-45.

14. Beutler E. Hemochromatosis: genetics and pathophysiology. Annu Rev Med. 2006;57:331-47.

15. Calado RT, Franco RF, Pazin-Filho A, et al. HFE gene mutations in coronary atherothrombotic disease. Braz J Med Biol Res. 2000; 33(3):301-6
16. Raymond M. \& Rousset F. GENEPOP, version 1.2: population genetics software for exact tests and ecumenicism. J. Heredity 1995;86:248-24916.

17. Andersen RV, Tybjaerg-Hansen A, Appleyard M, et al. Hemochromatosis mutations in the general population: iron overload progression rate. Blood. 2004;103(8):2914-9.

18. Strachan T, Read AP. Genética Molecular Humana. $2^{\mathrm{a}}$ ed, Artmed, Porto Alegre 2001; pp. 64-66.

19. Agostinho MF, Arruda VR, Basseres DS, et al Mutation analysis of the HFE gene in Brazilian populations. Blood Cells Mol Dis. 1999;25(5-6):324-7.

20. Martinelli AL, Franco RF, Villanova MG, et al. Are haemochromatosis mutations related to the severity of liver disease in hepatitis C virus infection? Acta Haematol. 2000;102(3):152-6.

21. Jackowski D, Rebello ES, Fauccz, FR. Análise da freqüência da mutação C282Y na população paranaense. Revista Estudos de Biologia 2004;26(55):11-8.

22. Perícole FV, Alves MA, Saad ST, Costa FF. Hemochromatosis (HFE) gene mutations in Brazilian chronic hemodialysis patients. Braz J Med Biol Res. 2005;38(9):1321-4.

23. Acton RT, Barton JC, Passmore LV, et al. Relationships of serum ferritin, transferrin saturation, and HFE mutations and self-reported diabetes in the Hemochromatosis and Iron Overload Screening (HEIRS) study. Diabetes Care. 2006;29(9):2084-9.

Avaliação: Editor e dois revisores externos

Conflito de interesse: não declarado

Recebido: 23/02/2008

Aceito após modifcações: 14/04/2008 